\title{
Kenya Entangled in Proscribed Crimes of Terrorism and Violations of Human Rights Law
}

\author{
Peter Onyango O. \\ School of Law, University of Nairobi, Kenya \\ *Corresponding Author: peter.onyango@uonbi.ac.ke
}

Copyright $@ 2015$ Horizon Research Publishing All rights reserved.

\begin{abstract}
The Republic of Kenya is one of the youngest African States emerging from British Colonial power since 1963. Since then it has been caught up in series of terrorist attacks claiming damages and harms to civilians. As the State tends to comply with its international law obligations a number of issues are being raised especially from human rights law whether the government has acted within the law and in good faith. This research investigates the legality of terrorism and counter reactions emerging from the State authority.
\end{abstract}

Keywords Terrorism, Counter Terrorism, Heinous crimes, human rights, Judicial Review, Human Dignity, Derogation of rights, and Indiscriminate Attacks

\section{Background Analysis}

Despite the failure to have a commonly agreed interpretation of terrorism in the international law it is a fact that breaches of human rights law are beyond any reasonable doubt. The Fact Sheet No. 32 prepared under the auspices of the UN Office of the High Commissioner of Human Rights alludes that Terrorism is commonly understood to refer to acts of violence that target civilians in the pursuit of political or ideological aims. In legal terms, although the international community has yet to adopt a comprehensive definition of terrorism, existing declarations, resolutions and universal "sectoral" treaties relating to specific aspects of it define certain acts and core elements. In 1994, the General Assembly's Declaration on Measures to Eliminate International Terrorism, set out in its resolution 49/60, stated that terrorism includes "criminal acts intended or calculated to provoke a state of terror in the general public, a group of persons or particular persons for political purposes" and that such acts "are in any circumstances unjustifiable, whatever the considerations of a political, philosophical, ideological, racial, ethnic, religious or other nature that may be invoked to justify them." Ten years later, the Security Council, in its resolution 1566 (2004), referred to "criminal acts, including against civilians, committed with the intent to cause death or serious bodily injury, or taking of hostages, with the purpose to provoke a state of terror in the general public or in a group of persons or particular persons, intimidate a population or compel a Government or an international organization to do or to abstain from doing any act". Later that year, the Secretary-General's High-level Panel on Threats, Challenges and Change described terrorism as any action that is "intended to cause death or serious bodily harm to civilians or non-combatants, when the purpose of such an act, by its nature or context, is to intimidate a population, or to compel a Government or an international organization to do or to abstain from doing any act" and identified a number of key elements, with further reference to the definitions contained in the 1999 International Convention for the Suppression of the Financing of Terrorism and Security Council resolution 1566 (2004). ${ }^{[1]}$

UN General Assembly in its Resolution A/RES/60/288 of 2006 condemns crimes of terrorism in all its forms and manifestations. ${ }^{[2]}$ What is clear in the mind of every right thinking person is that the human cost of terrorism has been felt in virtually every corner of the globe and Kenya is not spared. It kills anyone without clear target. Women, children, the disabled and men find themselves victimized for reasons not clear to them.

This discussion researched paper is interested particularly in the judicial conundrum in which the Republic of Kenya finds herself, the war on terrorism and how she defends herself within the law. The paper shall examine some critical episodes of terrorism attacks on Kenya and how the State has deployed some counter terrorism measures to quell the crime from its national borders. The prominent question is whether the de facto counter terrorism approach is within the law or it is also violation of human rights as has been adversely alleged by some human rights lawyers?

\section{Attacks on the Kenyan Integrity}

There is no doubt that when Kenya was attacked on $7^{\text {th }}$ August 1998 it appeared to be all against the United States of America and its foreign interests. The attack on the US Embassy was one of the heinous crimes felt in Kenya that 
left over 244 civilians killed, 12 American nationals and many others wounded. Such attack was severely condemned by the USA, Kenya and the rest of the world as unacceptable. The USA launched a criminal investigation through its Department of Defence and Justice, the Federal Bureau of Investigation (FBI) to detect the perpetrators. The result revealed some Somali nationals most of whom have since been killed were involved. Al-Qaeda terrorist network claimed the responsibility of the attack. ${ }^{[3]}$ US fired Tomahawk missiles against Afghanistan and Sudan in military response to the attacks against her foreign embassies. ${ }^{[4]}$

On another large scale Kenya has been severally threatened and attacked by some organised terror groups including Al-Shabaab immediately the Government decided to enter the Republic of Somalia to fight the terror group and assist the government take control of the situation. The unfortunate attack on the Westgate Commercial Mall on $21^{\text {st }}$ September 2013 involving armed assailants from a section of Al-Shabaab was recorded as a terrorist criminal offence on the Kenyan security. The group whose intent was to terrorize Kenya, maim, and conditionally compel the government to pull out her military intervention known as Kenya Defence Force (KDF) from Somalia, caused fear.

This time round the target was not the United States of America and its foreign interests but the Republic of Kenya which left over 68 civilians dead and many others fatally wounded. In response Kenya immediately condemned the heinous act terming it terrorist attack and opened an investigation to prosecute the perpetrators in her national courts of law. The New York Police Department was involved in carrying out the criminal investigation in Kenya to support local police. ${ }^{[5]}$ No proper prosecution has been done on the offensive.

\section{The Position of the Government of Kenya}

Besides evident episodes of major international crimes the government of Kenya has suffered variant small and short term terrorist attacks. Such attacks usually present themselves in different forms. Most of them have been acts of crimes that can be dealt with by national criminal law other than international crimes of terror. Law courts have handled most of them according to the Kenyan penal code in force. However, the few cases of international terrorism that have been mentioned have been retaliation against the US Government and its strongholds.

The position of the Government of Kenya has been consistently on the support to the the elected Government of Somalia through the UN supported AMISOM that handles peace mission. The intention to withdraw its forces from the territory of Somalia is still remote and not within the plans of the near future. Kenya, through the rule of law and its anti-crime policies apply migration mechanisms to deal with trans-boundary acts of terrorism.

\section{Rule of Law and Human Rights}

The Constitution of 2010 under section 2(5)(6) holds that the general rules of international law shall form part of the law of Kenya; and any treaty or convention ratified by Kenya shall form part of the law of Kenya. Kenya has ratified most of the international criminal law including human rights laws and humanitarian conventions. The government has also passed international crimes Act 2008 to enable law courts to try crimes of international law and to domesticate some parts of the Rome Statute. International Crimes Division (ICD) ${ }^{[6]}$ of the High Court of Kenya pursuant to section 8(2) of the International Crimes Act of 2008 was established in December 2013.

Kenya is among many States that have ratified most of the International Conventions of Human Rights starting with the Universal Declaration of Human Rights and most of the legal instruments of the International Bill of Human Rights. It has ratified also regional African Charter of Human and People's Rights among other legal instruments that it can safely apply while prosecuting the suspects of crimes of terror.

The High Court of Kenya has jurisdiction over cases on terrorism, piracy cyber-crime, human trafficking, money laundering, small arms smuggling and drug trafficking. This judicial provision gives Kenya lots of opportunity to deal substantively with terror cases brought before it for adjudication and determination.

However, as has been evidenced, all this does not go without challenges and the questions on bails given to persons suspected of terror crimes. Some of those who have been given bail have since left the country and there is no much hope that justice shall be delivered. Some have been denied bail on the ground that they would assist the police in the investigations.

\section{Human Rights and Fundamental Rights of Terror Suspects}

Hasan Mahati Omar and another v Republic [2014] eKLR Criminal Division in the ruling made the following decision: In an application of this nature, the court must consider various factors and circumstances. One paramount consideration is whether the release of the individual will endanger public security, safety and the overall interest of the wider public. (See Republic vs Muneer Harron Ismail \& 4 others, H.C. Cr. Revision No. 51 of 2009). The bail was denied and this is the ratio decidendi from the dictum of the presiding judge: In considering what would be the fair and just thing to do in the matter before me, I had recourse to the words of Lord Taylor in the case of $\mathrm{R} v$ Smurthinaite [1994]1 All ER 898 at page 903, in which he said:

"Fairness of the proceedings involves a consideration not only of fairness to the accused but also, as has been said before, fairness to the public."

Denial of bail when justified in accordance with the law does not amount to the applicants' lose of their right to the 
presumption of innocence or to a fair hearing. The right to bail is not one of those illimitable rights under Article 24 of the Constitution.

The nature of the charges and the gravity of the punishment in the event of conviction were also contemplated in the ruling by Judge L.A. Achode. It shows how serious the Court holds crimes of terrorism from this ruling.

In petition 586 of 2012 between Bashir Jama Abdi v Minister for immigration and Registration of Persons and 2 others Judge Isaac Leneola made a ruling that the said petitioner: (i) A declaration that by denying the subject Abdi Bashir Mohamed alias Cabdiqani Bashir Maxamed entry into Kenya and deporting him to the UK without a formal process or service on him of any written allegations, reasons or order/s and without according him a hearing, to contact his family or counsel, to appeal against the order of denial of entry into Kenya and deportation to the UK, was a violation of the subject's fundamental rights and freedoms as to equal treatment and equal action/justice, to deprivation of the society and recognition of his family under Articles 27(1), 45(1) and 47 of the Constitution.

(ii) An order of mandamus and/or mandatory injunction compelling the 1st and 2nd Respondent to facilitate, and expedite the processing of an application for regaining Kenyan citizenship by the subject Abdi Bashir Mohamed alias Cabdiqani Bashir Maxamed in his name of birth of "ABDI BASHIR MOHAMED" at any of the Kenyan diplomatic missions abroad and for a decision to be made one way or the other regarding that application.

The Court applied human rights provisions and made reference to European Human Rights Court rulings in order to inform its decision on the matter. The Ministry of Immigration and Registration of persons lost the case.

In the criminal case between the Republic $\mathrm{v}$ Issa Timmamy Judge Muya at Mombasa High Court made a ruling that the defendant be granted the bail under human rights and fundamental freedoms featuring in the Constitution of Kenya. The prosecution argued that the accused might interfere with investigations.

Persons charged with crimes of terror are also right holders and are entitled to Court bail, access to their advocate and contact with their family members. At the same time the detention without trial prohibited by the laws of Kenya advocate the freedom of the person while attending the trials as required until the conclusion of the case. Denial of right to be heard has rendered trial of crimes of terror very difficult in the corridors of justice in Kenya as the State seeks other options.

\section{Human Rights Account on the Counter Terrorism Measures}

Terror cases have been recorded while the complication of adjudicating such crimes has compelled the government to resort to military necessity to curb terror networks within its jurisdiction. The operation known as Linda Inchi by regular police force (Anti-Terror Unit of Police) and KDF lead by Kenya army has been accused of violations of human rights during certain operations. ${ }^{[7]}$ An example is the operation in Eastleigh estate in Nairobi where the presence of Somali community is strong. The forces were accused of breaching the privacy of civilians and treating Somali ethnic community inhumanely and without regard to human rights and dignity.

Shoot to kill policy has been condemned by human rights lawyers as a breach to human rights of due process of law and fair trial meant for all human persons. The principle of one is assumed innocent until proven guilty that is borrowed from the common law system is violated by the shoot to kill or extrajudicial killings. ${ }^{[8]}$

Forceful evacuation and transportation of persons to refugee camps or expulsion of persons perceived to be of Somali origin have been some of the most common allegations and outcry. Strict migration laws and policies, stringent conditions of foreigners residing in Kenya and the movement of population have made it difficult for individuals to exercise their rights and freedom in Kenya.

Human rights law requires that the State authority must promote, protect and enhance all rules of human rights to her citizens. ${ }^{[9]}$ Any act that violates such rights is usually challenged in Court. Due to this kind of friction between the Judiciary and the Executive, shoot to kill orders have been made to empower the police to use their guns to shoot down any person suspected to be a terrorist without right to be heard.

At the same time the State must keep vigilant of her obligations in the international law to safeguard the security of her citizens and the people within her jurisdiction. This must be done in light of international human rights standards at all-time save the time of war.

\section{Extrajudicial Killing}

Kenya finds herself in the midst of international war on terrorism. Such war that was declared by President George W. Bush after the attack on Manhatten in New York on $11^{\text {th }}$ September 2001 has not ended. Kenya is one of the States that despite her low participation in the war has suffered the consequences of the war. Ill prepared maybe, Kenya must only join the alliance that fights terrorism without becoming the bedrock of the crime as has been the case in the neighbouring Somalia.

The tactics of terrorism keep on changing with time. ${ }^{[10]}$ In Kenya, there have been allegations of Al-Shabaab recruiting Kenyan nationals in Somalia to join attacks against the sovereignty ${ }^{[11]}$ An allegation that has been proved by some young Kenyans who have been involved in terror attacks. Such behaviour has affected Churches, Mosques, public buses, pubs and any other overcrowded area in the cities.

Some criminals also adopt terror tactics to create fear as has been experienced in Mpeketoni town under Lamu County in Kenya. ${ }^{[12]}$ Several such crimes are now unfolding 
in different formats weakening the security sector. The County governor was arrested and arraigned Mombasa law Court for prosecution of the perpetration in such attacks.

Similar terror crimes are also felt in the sector of wild life. Criminals have switched to trading in elephant tusks to raise funds for their criminal objectives, a situation that is making Kenya think of more stringent legislations against poaching. Money laundering, drug trafficking and corrupt deals are some of the aspects of national crimes that graduate themselves with time into high level terrorism.

Killing of Sheikh Aboud Rogo Mohammed in 2012 provoked riots and some burning of Churches in Mombasa and some people accused the government. Till date no suspect has been prosecuted. ${ }^{[13]}$

Killing of Sheikh Abubakar ${ }^{[14]}$ known as Masanduku created more suspicion of police killing but this has since been denied by the government. No prosecution has ever been done and there is no clear investigation on the alleged crimes.

The rule of law and human rights provide that one is to be arraigned in law Court and due process of law and fair trials must be respected. No one shall be subject to arbitrary persecution and has a right to remedy by competent judicial authorities.

\section{Conclusive Remarks}

The Republic of Kenya has had rough time with its security and international relations due to terrorism affecting its image world-wide. At the same time the State must be seen to be respecting and implementing human rights according to her international obligations. All this put together the State is considering humanitarian approach to make peace with her neighbours and diplomatic approach to hearts and minds of terrorists. But the question is how effective will this be?

Unless addressed by high skilled experts Kenya should deploy highly skilled experts and train its security forces and the judicial officers to find the best way of dealing with terrorism without injuring human rights justice. Jihadist radicalization of the youth is another challenge that the State of Kenya must cope up with. ${ }^{[15]}$ It is a process that see many jobless nationals joining terrorist networks.

Al-Shabaab, the Somali militia currently fighting against African forces in Somalia, has seen varying degrees of success in its regional recruitment efforts. As it continues to struggle against the forces of the African Union Mission in Somalia (AMISOM), the militia has tried to step up these efforts. To this end, the group has seen significant success in countries such as Kenya, while it has struggled in Somaliland. The strategies and tactics employed by al-Shabaab in order to successfully recruit vary depending on geographical location, as do the motivations to join, and drawing on fieldwork in both Kenya and Somaliland this study will compare and contrast the effectiveness al-Shabaab recruitment in both of these countries. In doing so, it will examine which local conditions either enhance or limit these efforts, identifying some of the determinants of the success and failure of jihadist recruitment in east Africa. ${ }^{[16]}$

Somali investment in Kenya is another fact that the State must cope up with for the sake of security. Since it is not known the financial network of Al-Shabaab in the region the question of investment is vital in the fight against terrorism in Kenya.

It is true that terrorism is an international problem but it is also correct to allege that States such as Kenya must have proper framework that will deal with the crime without fringing on human rights.

Kenyan legal system still requires expansion work on the human rights law and to develop jurisprudence in that regard.

\section{REFERENCES}

[1] 'Factsheet32EN.pdf'.

[2] 'UN RESOLUTION.pdf'.

[3] 'The Trail Of Evidence - Fbi Executive Summary - Hunting for Bin Laden' (FRONTLINE) <http://www.pbs.org/wgbh/p ages/frontline/shows/binladen/bombings/summary.html> accessed 6 August 2014.

[4] 'Fast Facts: The Embassy Bombings in Kenya and Tanzania' (CNN)

$<$ http://www.cnn.com/2013/10/06/world/africa/africa-embas sy-bombings-fast-facts/index.html> accessed 6 August 2014.

[5] 'NYPD Investigation into Kenya's Westgate Mall Terror Attacks Reveals the Truth behind the Massacre of More than 60 Civilians' (NewsComAu) $<$ http://www.news.com.au/worl $\mathrm{d} /$ nypd-investigation-into-kenyas-westgate-mall-terror-attack s-reveals-the-truth-behind-the-massacre-of-more-than-60-civ ilians/story-fndir2ev-1226780483902> accessed 6 August 2014.

[6] 'Kenyan International Crimes Division to Be Realised Mid-2014' (Sabahionline.com) <http://sabahionline.com/en GB/articles/hoa/articles/features/2013/12/16/feature-01> accessed 6 August 2014.

[7] 'Operation Linda Nchi', , Wikipedia, the free encyclopedia (2014)

$<$ http://en.wikipedia.org/w/index.php?title=Operation Linda _Nchi\&oldid=609881365 $>$ accessed 6 August 2014.

[8] 'Standard Digital News : : The Counties - Police Issue Shoot to Kill Order on Terrorism Suspects' $<$ http://www.standardmedia.co.ke/thecounties/article/200010 7870/police-issue-shoot-to-kill-order-on-terrorism-suspects> accessed 6 August 2014.

[9] Joseph Wronka, Human Rights and Social Policy in the 21st Century a History of the Idea of Human Rights and Comparison of the United Nations Universal Declaration of Human Rights with United States Federal and State Constitutions (University Press of America 1992).

[10] Gregory E Maggs, Terrorism and the Law Cases and Materials (American Casebook) (West Group Publishing 2005). 
[11] John C Amble and Alexander Meleagrou-Hitchens, 'Jihadist Radicalization in East Africa: Two Case Studies' (2014) 37 Studies in Conflict \&amp; Terrorism 523.

[12] 'Standard Digital News : : The Counties - Lamu Governor Issa Timamy Arrested over Mpeketoni Killings' $<$ http://www.standardmedia.co.ke/thecounties/article/200012 6013/lamu-governor-arrested-over-mpeketoni-killings> accessed 6 August 2014.
[13] 'LIBYA: Two Abductions' (2013) 50 Africa Research Bulletin: Political, Social and Cultural Series 19887C.

[14] Edward F Mickolus and Susan L Simmons, The Terrorist List (ABC-CLIO 2011).

[15] Amble and Meleagrou-Hitchens (n 11).

[16] Ibid. 